\title{
M.Megre
}

\section{BRAZIL's ENERGY SECURITY: DEFINING THE AGENDA}

DOI: $10.20542 / 2307-1494-2019-2-74-87$

\begin{abstract}
In the past decades Brazil grew in power and influence as an energy producer and consumer both in regional and global arenas, having become an important player at international energy markets. Its privileged geographic location gives the country several advantages, such as a broad diversity of raw materials and energy sources: biofuels, hydropower and fossil fuel (especially petroleum and natural gas). At the same time, other sectors of the Brazilian economy have a strong influence on how the energy industry develops and organizes itself domestically and abroad. The article analyzes key issues of the Brazilian energy security and defines its agenda. Through this lens, structural factors and shapers of Brazil's energy sector, including political influence, administration and regulation of its energy system, are explored.
\end{abstract}

Keywords Brazil, energy security, "Petrobras", renewables, hydropower, transmission network, blackout

\section{Название Энергетическая безопасность Бразилии: определяя повестку статьи}

Аннотация В последние десятилетия Бразилия нарастила свое региональное и глобальное влияние в качестве как производителя, так и потребителя энергии, став важным игроком на международных энергетических рынках. Выгодное географическое положение дает стране несколько преимуществ, включая широкое разнообразие таких энергетических и сырьевых ресурсов, как биотопливо, гидроэнергия и ископаемое топливо, особенно нефть и природный газ. Вместе с тем другие секторы бразильской экономики оказывают сильное влияние на развитие энергетики и на систему ее организации внутри страны и за рубежом. В статье рассматриваются ключевые проблемы энергетической безопасности Бразилии и концептуализируется ее повестка. В этом контексте рассматриваются структурные условия и фракторы фрормирования бразильского энергетического сектора, включая политическое влияние, проблемы администрирования и регулирования.

Ключевые Бразилия, энергетическая безопасность, “Petrobras”, возобновляемая энергия, слова гидроэнергия, сеть электропередачи, блэкаут

\section{Energy Security}

The term "energy security" has been widely used by international and national bodies, organizations, interest groups and individuals from different spheres, such as political, economic, military, environmental and so forth. General understanding of the term usually

Milena Megre (Brazil) is a student of MGIMO University (Moscow). Милена Мегре - студентка МГИМОУниверситета. 
takes into consideration the concepts of uninterrupted energy supply, continuous energy availability, and affordable price. The International Energy Agency (IEA) defines energy security as "the uninterrupted availability of energy sources at an affordable price" and differentiates between long-term "investments to supply energy in line with economic developments and sustainable environmental needs" and short-term energy security understood as "the ability to react promptly to sudden changes within the supply-demand balance". ${ }^{1}$ According to the United Nations, which distinguishes between importers and exporters, "the standard definition of energy security [...] concerns security of supply" and "energy exporting countries" that "means stable energy export flow at a 'reasonable' price that can assure not only new energy investment but also general economic development".

These concepts are regarded and treated differently by different types of energy actor. Some may include other concepts, such as self-sufficiency, gas emission reduction, renewable fuels, high flux of exports, uninterrupted supply of import, and ability to stock energy. On the one hand, specific insights into energy security come from the very notion of security itself, ideas of what constitutes a "threat", and of how to manage it. On the other hand, ideas of "energy security" vary according to the specific national and regional realities, may be largely focused on specific priority topics for particular states, and are intrinsically correlated to specific political interpretation of "security threats" by various actors. ${ }^{3}$ For the European Commission, the EU's energy security revolves around the idea of uninterrupted energy supply from its imports and diversification of suppliers needed to avoid becoming dependent on imports from any single country. ${ }^{4}$ As for those countries whose energy infrastructure is under the threat of terrorist attacks, such as Colombia, Pakistan, ${ }^{5}$ Iraq, and Syria, ${ }^{6}$ protection of infrastructure is strongly emphasized in their approaches to energy security.

The author of this article tries to define what "energy security" means and what it encompasses for Brazil. It is important to determine what kind of an energy actor Brazil is, what are the main energy-related issues and threats that the country faces, and how Brazil deals with these issues.

\section{Outlook on Brazilian energy}

The energy industry has a large importance for the Brazilian economy. It makes a fair share of national exports and imports and accounts for some 1/10 of the country's GDP. In the 21st century, Brazil consolidated its influence as a leader in the energy market of Latin America, accounting for one third of the energy production in the region and becoming its largest consumer. ${ }^{7}$ As a regional energy leader, Brazil plays an important role in the global energy sector as well, due to broad diversity of its energy resources, the growing role of renewables in its energy mix, and its extensive reserves of petroleum.

The largest component of Brazil's Energy mix is fossil fuel (petroleum and derivatives - $36 \%$, natural gas - 13\%). One of the main sources of Brazil's fuels is the so called "Pré-Sal" (pre-salt) - a large reserve located at the Brazilian coast in the Atlantic Ocean. In this reserve, both oil and natural gas of high quality can be found, but the extraction process is quite laborious, as it is necessary to drill into a thick layer of salt and marine sediments to access the resources.

The largest share of the Brazilian energy mix can be attributed to petroleum production. Brazil is one of the ten largest oil producers in the world and has a share of $3 \%$ 
of the world's total production (2018).$^{8}$ It is the third largest oil producer in the Americas, following the United States and Canada. ${ }^{9}$ Most of Brazilian oil reserves consist of heavy oil and are located in deep water offshore deposits. In the 2010s, Brazil started to diminish its petroleum imports and almost doubled its exports. Brazil exports heavy oil (that makes $7.9 \%$ of total national exports), mostly to China (36\%), USA (24\%), Chile (15\%), Spain (8\%), India $(7 \%)$, and Uruguay (3\%). ${ }^{10}$ Brazil also imports light oil from abroad (8.1\% of total imports) ${ }^{11}$ mostly from Saudi Arabia (48\%), Algeria (25\%), Nigeria (16\%), and Iraq (4\%). ${ }^{12}$ This interconnected system of oil production, exports, and imports is a lifeline for Brazil's economy. While the energy sector brings tangible economic and political benefits, Brazil has become quite dependent on it. This actualizes the energy security agenda for the nation.

Petroleum production in Brazil is mostly done by "Petrobras" - a public company, with the Government of Brazil as a major shareholder. "Petrobras" represents an essential part of Brazilian economy, due to its primarily role in exploration, production, refining, marketing and transportation of oil, natural gas and its derivatives. "Petrobras" alone was responsible for $13 \%$ of the GDP of Brazil in $2014^{13}$ and for $94 \%$ of the national oil production of $2017,{ }^{14}$ while other companies accounted for only $6 \%$ of oil production. Hence, the company is a key player for the country's imports and exports.

Table 1. Data on natural gas

\begin{tabular}{|c|c|c|c|c|c|c|c|c|}
\hline million $\mathbf{~ m}^{\mathbf{3}}$ / day & $\mathbf{2 0 1 2}$ & $\mathbf{2 0 1 3}$ & $\mathbf{2 0 1 4}$ & $\mathbf{2 0 1 5}$ & $\mathbf{2 0 1 6}$ & $\mathbf{2 0 1 7}$ & Average & Percentage \\
\hline Total demand & 75.03 & 91.34 & 99.26 & 98.63 & 80.26 & 85.56 & 88.34 & 100 \\
\hline Total offer & 78.91 & 95.05 & 105.10 & 102.58 & 84.54 & 89.83 & 92.66 & 104.8 \\
\hline Total imports & 36.04 & 46.47 & 52.93 & 50.43 & 32.13 & 29.37 & 41.22 & 46.6 \\
\hline $\begin{array}{c}\text { National offer } \\
\begin{array}{c}\text { Imports from } \\
\text { Bolivia }\end{array}\end{array}$ & 27.87 & 48.57 & 52.17 & 52.15 & 52.40 & 60.46 & 51.43 & 58.2 \\
\hline
\end{tabular}

Source: Ministry of Mines and Energy, Brazil. ${ }^{15}$

The second largest fuel in both energy and electricity mix is natural gas. While Brazil can also find natural gas on land, most of it is found and extracted from the sea, from PréSal reserve. "Petrobras" is the company that has the largest share not only of oil, but also of natural gas production (93.7\%). ${ }^{16}$ In the past ten years, the daily production of both land and sea natural gas increased by $86.3 \% .{ }^{17}$ However, by comparing the total demand and the Total offer (see Table 1), one can see that, despite the production increase in 2012-2017, the average total demand for gas was still higher than the volume of production, meaning that Brazil still had to import gas (primarily from Bolivia) to meet its national demand. Brazil tries to diminish its dependence on gas imports by increasing its production to meet the domestic demand. This demand comes mostly from the industrial sector $(47.65 \%)$ and increasingly from electricity generation $(40.03 \%){ }^{18}$ 
Despite the prevalence of fossil fuels in the country's energy mix, renewable energy accounts for impressive $42.9 \%$ while the electricity mix is dominated by hydropower $(62.5 \%)$ and by renewables as a whole ( $82 \%)$. Hydropower provides the country with a place among the five top renewables consumers in the world, ${ }^{19}$ but, as it will be demonstrated later, this also makes the country vulnerable in terms of its energy security. Apart from hydropower, wind energy and sugar cane become increasingly important for electricity generation. As for transportation fuels, Brazil is the second world largest producer of biodiesel ${ }^{20}$ and bioethanol ${ }^{21}$ from soy that are also used as alternatives to oil derivatives.

Figure 1. Brazilian energy mix (2017)

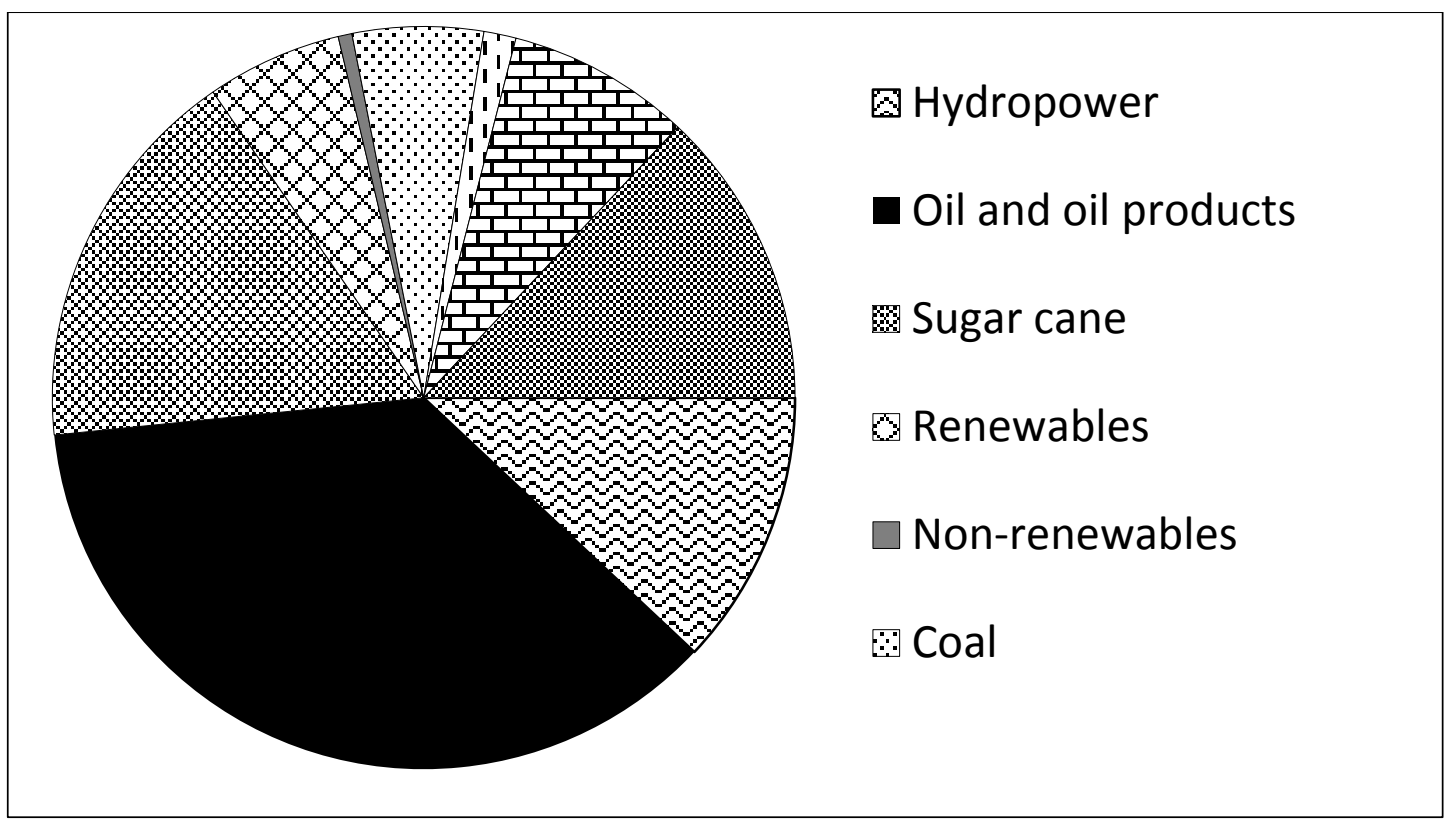

Source: Agência Nacional de Energia Elétrica [National Agency of Electricity]. ${ }^{22}$

Since 1990s, Brazil adopted several reforms in its energy sector in order to ensure greater stability of energy supply. Several measures were aimed at fostering bilateral cooperation to ensure energy imports from such neighboring countries as Argentina, Bolivia and Paraguay. Most measures were related to the liberalization of the market, facilitating investments from national and international actors and privatization of energy companies.

Among other things, liberalization greatly affected Brazil's regional energy management systems. There are two levels of administration: national and regional level (the Brazilian territory is divided into 26 states and 1 federal district). Previously, each state had a state-level company working exclusively for that state, but today it is no longer the case. Some states have several energy companies (private or state-owned), and some of the companies that had initially been state-owned, were bought and privatized. At present, $60 \%$ of energy companies in Brazil are private. ${ }^{23}$ 
Figure 2. Brazilian electricity mix (2017)

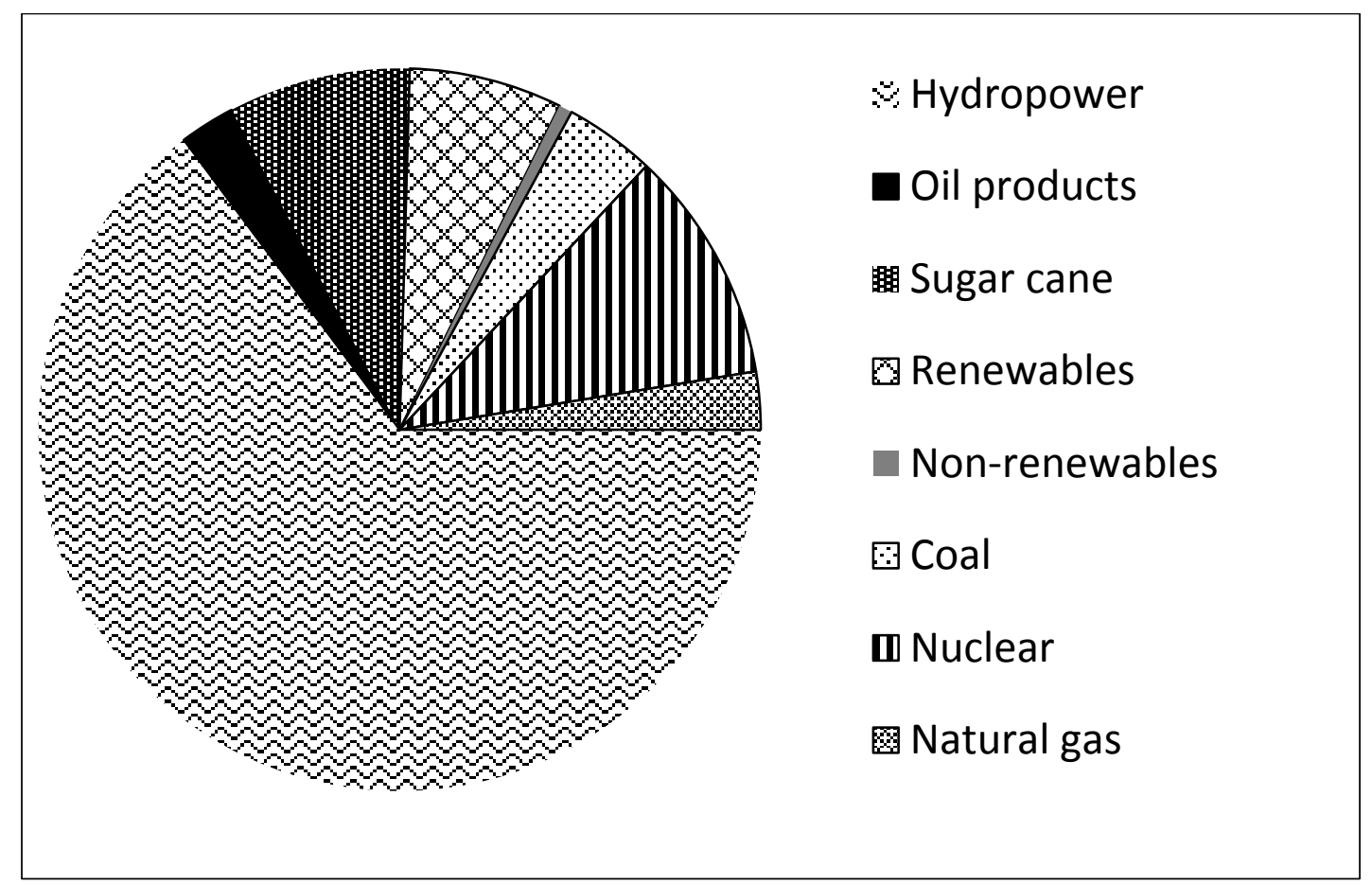

Source: Agência Nacional de Energia Elétrica. ${ }^{24}$

\section{Political issues: the impact of the "Petrobras" scandal}

Having a stable government that implements efficient policies towards the energy market is highly desirable for the energy sector and for energy security in particular. To illustrate seriousness of the impact that politics and political stability have upon the energy market, the case of the "Petrobras" scandal has to be considered.

While "Petrobras" significantly contributed to Brazilian growing international influence and to development of its energy potential, the company has suffered great losses and has been buried in debts as a result of the 2015 corruption scandal. This scandal broke out in the context of "Car Wash Operation" (Operação Lava Jato) that discovered a money laundering scheme involving "Petrobras". This scheme also involved high-standing officials and members of political parties and CEOs of major companies. Among those accused of corruption, money laundering, and other financial crimes, was even a left-wing president Dilma Rousseff herself. The scandal led to impeachment of the president who was replaced by her unpopular vice-president Michel Temer for a period since mid-2016 until the end of 2018. After a turbulent series of events that exacerbated splits in the Brazilian society, one of the most controversial presidential elections of October 2018 brought to power a rightwing politician Jair Bolsonaro.

As for "Petrobras" itself, its financial situation deteriorated dramatically. Amid the scandal, the new CEO, Aldemir Bendine, announced in 2015 that the company was burdened by some BRL 500 billion (USD 130 billion) debt. $^{25}$ 
Political turbulence was reflected in changes in governmental energy policies, as one can see comparing respective measures taken by three above-mentioned presidents. Prior to the scandal, Dilma Rousseff revived a plan from the 1980s of constructing a fully Brazil-owned "Belo Monte" hydropower plant. Despite criticism, Rousseff believed that this was an important step towards self-sufficiency, since the biggest hydropower plants in Brazil were binational. In 2016, this power plant was inaugurated, ${ }^{26}$ becoming the third largest one in the world. She also secured extension of "Oil and Natural Gas Exploration Strategy" that was not only aimed at expanding exploration areas, but directly entrusted "Petrobras" to implement this task, increasing the company's role in the market of oil and gas and in the Pré-Sal area even more. ${ }^{27}$

After the Car Wash scandal erupted and caused a severe political crisis, the succeeding president Temer adopted a new policy towards "Petrobras" in $2016 .{ }^{28}$ This policy included international parity pricing which meant that prices for domestic fuels would follow the relevant trends in the international market. This would impact reduction or increase in prices offered by refineries and also lead to more frequent adjustments in domestic energy prices due to the fluctuations in the international market. The new pricing policy was subjected to heavy criticism and had a direct impact on the country in 2018. Another remarkable measure was the approval of "RenovaBio" ${ }^{29}$ - a state policy which recognizes the strategic role of biofuels in Brazil's Energy Mix. This policy is considered to be an important step to safeguard the country's energy security and to fulfill its commitments under the Paris Agreement.

During the term of president Bolsonaro, the minister of economy Paulo Guedes and the minister of energy Bento Albuquerque have worked in cooperation with CADE (Administrative Council for Economic Defense), ANP (National Agency of Petroleum, Natural Gas and Biofuels), and CNPE (National Council of Energy Policy), in order to break the monopoly of "Petrobras" on supply, infrastructure, logistics, and distribution pipelines. To achieve this aim, in June 2019, the Ministry of Mines and Energy launched a plan called "The New Gas Market" ${ }^{30}$ that proclaims a new phase of open competition and free market. ${ }^{31}$ The government tries to create more space for new companies, in order to increase competitiveness for gas prices in the market. The government believes that this will result in a fall in the prices for gas sold inside the country and thus generate a positive impact on electricity bills, industry activity, and creation of new jobs.

In general, dramatic instability and abrupt political changes had a great impact on Brazilian energy policies. The country, which was governed by the same party for more than ten years, suddenly faced three different political approaches towards the energy sector, that resulted in irregular strategic course and unstable energy markets.

\section{Regional relations}

At the international level, both regional and global energy issues and dimensions matter. This section discusses regional agendas, focusing on South America, and, more precisely, on MERCOSUR - the bloc that consists of Argentina, Brazil, Paraguay, Uruguay, and Venezuela as member states and Chile, Peru, Colombia, and Ecuador as associates (also, Bolivia is in the process of accession). Among other things, cooperation with these countries is highly important for Brazil as an energy importer, exporter and producer. Specifically, the two largest hydropower plants of Brazil are binational: one shared with 
Paraguay and another with Argentina. Another example of importance of regional energy relations is Bolivia - Brazil's main source of gas imports (that accounts for $27-35 \%$ of gas imports). As it is necessary for Brazil to import gas from Bolivia, in order to meet its national demand, stable friendly relations between the two governments are highly important for it. If Brazil no longer has Bolivia as a source of gas imports, it would be not easy for the former to replace a large Bolivian share with its own production or with imports from other countries.

Energy relations with Venezuela also matter for Brazil even despite the fact that the former has been currently suspended from MERCOSUR for political reasons. ${ }^{36}$ Venezuela, by some accounts, has the largest reserves of oil in the world, and its production accounts for $90 \%$ of the country's export. ${ }^{32}$ While Brazil is not a major destination for oil exports from Venezuela, it does import cheap Venezuelan hydroelectricity to supply Roraima - the only Brazilian state that is not interconnected with the Brazilian electrical system or with the National Interconnected System (SIN). ${ }^{33}$ Roraima has already been dependent on electricity supply from Venezuela for 18 years and thus is very sensitive to the state of diplomatic relations between the two nations, that have been deteriorating. There is also an issue of USD 33 million debt by the Brazilian government that has been unable to transfer the payment due to the US financial sanctions against Venezuela. ${ }^{34}$

\section{Global energy market issues}

Fluctuations of global energy prices seriously affect Brazilian economy. This makes the country vulnerable to those changes in international politics and economics that seriously affects global energy markets. Long before liberalization of the Brazilian energy market occurred in the end of the 20th century, the 1970s OPEC's oil embargo and the global oil price surge following the 1979 Iranian Revolution had led to drastic economic decline, inflation, and doubled national debt for Brazil. ${ }^{35}$

Currently Brazil still suffers from unfavorable trends in global energy markets. In May 2018, the country went through a major crisis due to skyrocketed prices for gasoline and diesel stemming from president Temer's new pricing policy that linked fuel prices to the rate of the U.S. dollar. The so-called "Truckers' Strike", or "Diesel Crisis", involved a campaign by truck drivers who paralyzed roads to protest against high fuel prices. As transportation of goods (such as food and medicines) in Brazil is done by road, food supply to supermarkets was interrupted and the population started to stock up food. Several regions had their roads blocked and declared a state of emergency. Inflated fuel prices produced panic: people started to go in mass to gas stations, staying in lines for hours to fill their tanks in anticipation of further fuel price surges. The government's immediate response was to use the armed forces to unblock roads. ${ }^{36}$ Later, the government introduced interim measures aimed at holding further price adjustments for no less than 60 days, reducing fuel prices by the end of the year, and exempting truck drivers from paying tolls in specific occasions. ${ }^{37}$

\section{National energy balance and dependence on hydropower}

To understand Brazil's place in global energy market and to assess how self-sufficient or energy dependent the country is, it is important to define which type of energy actor Brazil is: a major producer, consumer, or both. Usually, to determine whether a country is selfsufficient or dependent, it is necessary to compare key figures on energy production and 
consumption and to figure out if a country manages to produce enough for its own consumption. However, Brazil is quite a specific case that does not clearly fit such criteria.

In August 2019, Brazil's energy production reached 47,4 gigawatt hours (GWh), ${ }^{38}$ while consumption was 38,2 GWh. ${ }^{39}$ As for Brazil's energy trade, in 2017 the country exported 13 kilotonnes of oil equivalent (ktoe) and imported 3.1 ktoe. ${ }^{40}$ While Brazil is the third largest energy consumer in the Americas, ${ }^{41}$ its evidently positive energy trade balance may create an impression that the country is largely energy self-sufficient.

Yet, the reality is more complex and the Brazilian hydropower sector is a glaring example. It was already mentioned that hydroelectric plants provide almost three-quarters of electricity produced in the country. On the one hand, it was convenient for Brazil to rely on hydropower since the country ranks the third in the world by electricity generation, following Russia and China. ${ }^{42}$ Reliance on hydropower provides grounds for considering Brazil a renewable country. On the other hand, this makes Brazil dependent on this sector, as it has not been able to cope with the increase in demand that came from industrialization and population growth of the past ten years. Consequently, the country has to import electricity for its consumption. The fact that the largest hydroelectric plant in Brazil (which is also the second largest in the world) does not belong entirely to Brazil makes the country even more dependent. "Itaipu Power Plant" is located on the border of Brazil and Paraguay, meaning that both countries have equal $50 \%$ shares of the plant's total production. Paraguay is unable to consume its share in full and sells the surplus to Brazil. The same applies to the Brazil-Argentine binational plant "Garabi": Brazil also buys energy produced by its neighbor. This explains why president Rousseff believed that investing in a fully Brazilian hydropower plant would be an effective measure to safeguard Brazil's future self-sufficiency.

One of the reasons why Brazil has to import electricity, despite its strong hydropower sector, is that sector's seasonal instability. The period of May to July is a dry season when the country suffers from absence of rainfall. If rainfall is below $75 \%$ of the average, it damages energy supply and frequently causes blackouts, since hydroelectric dams rely on adequate levels of water in their reservoirs to generate energy. The levels of the reservoirs can change not only due to rainfall, but also because of natural evaporation and unstable level of daily energy consumption. To tackle this issue, Brazil has bilateral agreements with its neighbors, for instance, with Argentina and Uruguay, ${ }^{43}$ to import a certain amount of energy in cases of emergency. Another measure for such cases is a resort to thermoelectric plants that are considerably more expensive and enhance energy costs for consumers. In February 2019, thermoelectric plants accounted for $64 \%$ of electricity generation for the largest region in Brazil, as a consequence of the low rainfall rates, quite unusual for that season. ${ }^{44}$

Thus, Brazil can be considered both as a major producer ${ }^{45}$ and consumer. $^{46}$ In any case, the country cannot be considered as energy self-sufficient due to mismanagement and inability to take adequate measures to diminish its dependence and handle unexpected events. Brazil is trapped in a vicious cycle of relying on hydropower and depending on external actors to safeguard sufficient supply in cases of shortage and emergency.

\section{Transmission networks and blackouts}

Brazil's large territory and great distances between power generating units (usually hydropower plants) and consumer centers make issues such as energy losses and unstable 
energy supply to final customers particularly problematic. The largest consumers of electricity are major urban centers and industrialized regions.

In this case, the problem is not only in fluctuating rainfall level. Other serious issues are overexploitation and lack of environmental concern about water sources. Poor distribution of water, deforestation, and regional and political conflicts are some of the factors that contribute to water scarcity in Brazil. Distribution of water resources is an especially serious problem. Brazil has five main regions (listed in order from the most populous to the least one): Southeast, Northeast, South, Center-West, and North. Most hydropower plants in Brazil are located in the northern part of the country that is less inhabited than other regions (only $7 \%$ of the country's population reside in the north), ${ }^{47}$ but accounts for most of the country's water resources (68\%). ${ }^{48}$ In contrast, the bulk of Brazil's population concentrates in two regions: Southeast (43\%) and Northeast $(29 \%)^{49}$ where the largest urban centers are located. However, these regions only account for $7 \%$ (Southeast) and $3 \%$ (Northeast) of water resources. ${ }^{50}$ As a result, a large system of electricity transportation had to be built across the country to deliver energy created in the North to the Northeast and Southeast regions. Transmission networks largely consist of overhead cables fixed to large metal towers. Not only construction of this tower system is quite expensive, but its maintenance is costly as well. Due to large distances between power plants and most developed areas, a considerable amount of energy is lost on the way until it reaches final consumers.

The main problem caused by this configuration of the electricity transportation is Brazil's high vulnerability to blackouts. According to the Nation Association of Energy Consumers (ANACE), "blackouts becomes more frequent each year" and "major blackouts became a routine in Brazil". 51

One of the most remarkable examples dates back to 2001-2002 when Brazil experienced a major energy crisis. The crisis occurred due to poor planning and lack of investments in generation and distribution of energy and was aggravated by the scarcity of rains in those particular years. Consequently, water levels in reservoirs of hydroelectric dams fell drastically and the population was forced to ration energy. An additional reason for the blackout was steady increase in energy consumption due to population growth and growing industrial production. ${ }^{52}$

Among other things, blackouts have been caused by mismanagement. For instance, when a specific plant suffers from low reservoirs levels and is unable to fulfill the demand of its respective region, this plant should be sealed off and an emergency plan of supply for this region should be put into action. Instead, what usually happens is that the demand of that plant is transferred to another one which becomes overloaded. In Brazil's interconnected hydroelectric system, this leads to forced shutdowns, producing a domino effect of shutdowns and blackouts.

Blackouts are a reality still faced by many regions. Suggestions on how to mitigate this issue vary. Some specialists propose short-term solutions that rely on non-renewable sources: for example, the Government of the Alagoas State claims that the optimal way out of crisis is to increase the use of natural gas. ${ }^{53}$ Others believe in long-term investments in renewables to decrease the country's dependence by building a safer electricity mix to rely on. For instance, director of the School of Engineering Luciano Carstens argues that "to meet this urgency, the country needs to use new sources of energy, improve distribution and rationalize use. Alternative sources of energy such as wind, solar and biomass are 
already being explored". ${ }^{54}$ Brazil needs new plants for production, improvements in the distribution structure, and especially new sources of energy, in order not to depend exclusively on a particular energy source.

Overall, the issues considered in this section imply high importance of improving the electricity transmission networks in Brazil. Interrupted supply via these networks remains one of the biggest risks to national energy security. Among other things, this risk requires further energy imports and leads to Brazilian greater energy dependence on other nations.

\section{Conclusions}

Despite the fact that official energy policies vary depending on changing governments, it is possible to outline a relatively stable set of energy security issues for Brazil. It is clear that threats to security are nonlinear and one issue may impact other sectors thus creating a cascade effect.

Uninterrupted energy supply is one of the most persistent energy security problems faced by Brazil. For electricity, the whole system of production and transmission requires improvements to tackle a range of problems, including overreliance on hydropower, energy losses due to large distances between producers and consumers, and overdependence on individual power plants within interconnected national energy system. Brazil has also faced major difficulties in handling crisis situations and emergencies.

Dependence on hydropower as the main source for electricity production and on light oil suitable for Brazilian refineries creates a multiplier effect which makes the country vulnerable to (changes in) the policies of foreign partners. Brazil's energy security depends on good political relations with regional and some other suppliers of energy, as well as consumers of its energy exports. Growing exposure to global markets also makes Brazil more vulnerable to dramatic changes in prices, which creates an environment of uncertainty and can aggravate domestic political situation.

As the "Petrobras" scandal and blackouts demonstrate, it is essential for Brazil to decrease its dependence on a single energy resource and achieve greater diversification of its fuels and of companies operating at its energy market. In this light, transition to renewable energy is not exclusively a matter of becoming a carbon-free nation - it also decreases energy vulnerability of the country and, in turn, increases reliability of energy supply sources available to it.

Economic and political stability also does matter. Political turmoil and drastic changes, such as the ones seen in the past five years, undermine continuity of energy policy thus making it less effective in terms of responding to challenges.

In a nutshell, the key concepts of energy security for Brazil involve the principle of uninterrupted supply combined with the capacity to deliver it to the final consumer, diversification in the market of fuels, and better administration that could prevent an unforeseen event in advance or solve it. Additionally, Brazil's energy security involves safeguarding stable energy imports and exports through the maintenance and improvement of bilateral and multilateral cooperation. The country should adjust its priorities for the energy industry with greater focus and perseverance, as that it is not simply about producing more energy, but also about smart supply, strategic planning, and effective reforms in the administration of the energy system. Future prospects for Brazilian energy market could include moving towards self-sufficiency, to ensure reliable delivery systems and stable 
supply. If Brazil pursues self-sufficiency consistently, it could decrease its dependence on energy imports and domestic depletable sources while achieving a clean-energy efficiency that is in line with the current global development agenda.

\section{ENDNOTES}

\footnotetext{
1 What is energy security? // International Energy Agency. URL: https://www.iea.org/topics/energysecurity/whatisenergysecurity.
}

2 International energy security: common concept for energy producing, consuming and transit countries. Woluwe-Saint-Lambert: Energy Charter Secretariat, 2015. P. 13. URL: https://energycharter.org/fileadmin/ DocumentsMedia/Thematic/International_Energy_Security_2015_en.pdf.

${ }^{3}$ Belyi A. Reader: Energy Security in International Relations (IR) Theories. Higher School of Economics, 2012. P. 3. URL: https://www.hse.ru/data/339/636/1233/ReaderforLecturesOnEnergySecurity.doc.

${ }^{4}$ Energy Security // European Commission: An Official Web-site of the European Union. URL: https://ec.europa.eu/energy/en/topics/energy-security.

5 Toft P., Duero A., Bieliauskas A. Terrorist targeting and energy security // Energy Policy. V. 38. № 8. 2010. P. 4411-4421.

6 Tichý L. Energy infrastructure as a target of terrorist attacks from the Islamic state in Iraq and Syria // International Journal of Critical Infrastructure Protection. V. 25. 2019. P. 1-13.

7 Energy in South America (Year 2013). Ministério de Minas e Energia. 14.10.2014. P. 2-3. URL: http://www.mme.gov.br/documents/10584/3642004/04+-+Energy+in+South+ America+\%28PDF\%29/a8296ff1-824c-4382-9d12-5498b1eb5409;jsessionid= A1F393D6EB3B6AEF7C774CCA0DBFC8F0.srv155.

${ }^{8}$ What countries are the top producers and consumers of oil? The 10 largest oil producers and share of total world oil production in 2018. U.S. Energy Information Administration: Frequently Asked Questions (FAQs). URL: https://www.eia.gov/tools/faqs/faq.php?id=709\&t=6.

${ }^{9}$ Brazil: Executive Summary. International Energy Agency. 18.04.2019. URL: https://www.eia.gov/beta/ international/analysis.php?iso=BRA.

10 Boletim Anual de Exploração e Produção de Petróleo e Gás Natural 2017. № 5. 2018. P. 14. URL: http://www.mme.gov.br/documents/10584/2533848/Boletim+de+Exploração+e+Produção+de+ Petróleo+e+Gás+Natural+ano+2017/e570ced2-86e2-485b-85a0-2c8d0407b945?version=1.0.

11 Brazil. The Observatory of Economic Complexity (OEC) Country Brief. URL: https://oec.world/en/profile/country/bra.

12 Boletim Anual de Exploração e Produção de Petróleo e Gás Natural 2017. Op. cit. P. 14.

13 Participação do setor de petróleo e gás chega a 13\% do PIB brasileiro. Petrobras. 17.06.2014. URL: http://www.petrobras.com.br/fatos-e-dados/participacao-do-setor-de-petroleo-e-gas-chega-a-13-dopib-brasileiro.htm. 
14 Boletim da Produção de Petróleo e Gás Natural. № 90. 2018. P. 4. URL: http://www.anp.gov.br/ images/publicacoes/boletins-anp/Boletim_Mensal-Producao_Petroleo_Gas_Natural/Boletim-Producao _fevereiro-2018.pdf.

15 Ibid.

16 Boletim da Produção de Petróleo e Gás Natural. № 101. 2019. P. 4. URL: http://www.anp.gov.br/ images/publicacoes/boletins-anp/Boletim_Mensal-Producao_Petroleo_Gas_Natural/boletim-janeiro2019.pdf.

17 Boletim Mensal de Acompanhamento da Indústria de Gás Natural. № 5. 2018. P. 9. URL: http://www.mme.gov.br/documents/10584/2533848/Boletim+de+Exploração+e+Produção+de +Petróleo+e+Gás+Natural+ano+2017/e570ced2-86e2-485b-85a0-2c8d0407b945?version=1.0.

18 Boletim Mensal de Acompanhamento da Indústria de Gás Natural. № 130. 2017. P. 2. URL: http://www.mme.gov.br/documents/10584/0/Boletim_Gas_Natural_nr_130_DEZ_17.pdf/4ed1cec26b0b-42fc-a8c7-5ea5a2e23b10.

19 Dillinger J. Countries with the most renewable energy // WorldAtlas. 01.10.2018. URL: worldatlas.com/articles/top-15-countries-using-renewable-energy.html.

${ }^{20}$ Wang T. Leading biodiesel producers worldwide in 2018, by country (in billion liters) // Statista. 08.07.2019. URL: https://www.statista.com/statistics/271472/biodiesel-production-in-selectedcountries.

${ }^{21}$ Global Ethanol Production. U.S. Deparment of Energy. 02.11.2018.

URL: https://afdc.energy.gov/data/10331.

${ }^{22}$ Gomes V. Panorama geral do setor elétrico e governança setorial. Agência Nacional de Energia Elétrica. 2018. URL: https://www.aneel.gov.br/documents/655804/14752877/Panorama+geral+do+ setor+elétrico+e+governança+setorial_Victor.pdf/43046afc-c5ce-8f77-0f68-597e1dcfdfa0. P. 3.

${ }^{23}$ Portinari N. Empresas privadas já detêm $60 \%$ da geração de energia do Brasil. União Nacional da Bioenergia. 30.09.2017. URL: https://www.udop.com.br/index.php?item=noticias\&cod=1156180.

${ }^{24}$ Gomes V. Op. cit.

${ }^{25}$ Vital A., Assumpção R.C. Bendine: dívidas da Petrobras são quatro vezes o resultado anual da empresa. Câmara dos Deputados. 14.10.2015. URL: https://www.camara.leg.br/noticias/473030-bendinedividas-da-petrobras-sao-quatro-vezes-o-resultado-anual-da-empresa.

${ }^{26}$ Dilma inaugura usina hidrelétrica de Belo Monte. Ministério do Planejamento. 05.05.2016. URL: http://www.pac.gov.br/noticia/7be96908.

${ }^{27}$ Memória da 28a Reunião Ordinária. Ministério de Minas e Energia. 24.06.2014. URL: http://www.mme.gov.br/documents/10584/1819973/CNPE_Memoria_28_Reuniao_24062014_ Final.pdf/bb840f3b-878d-448a-a51a-bd1a7a13445a.

${ }^{28}$ Adotamos nova política de preços de diesel e gasolina. Petrobras. 14.10.2016. URL: http://www.petrobras.com.br/fatos-e-dados/adotamos-nova-politica-de-precos-de-diesel-e-gasolina.htm.

${ }^{29}$ RenovaBio. Nota Explicativa sobre a Proposta de Criação da Política Nacional de Biocombustíveis. Ministério de Minas e Energia. 2017. URL: http://www.mme.gov.br/documents/10584/135676503/Nota+ 
Explicativa+RENOVABIO+-+Documento+de+CONSOLIDACAO+-+site.pdf/2bc724d5-ae20-4da8-a401ecaed45f6a1f.

30 Governo lança o "Novo Mercado do Gás", um marco histórico para o Brasil. Ministério de Minas e Energia. 23.07.2019. URL: http://www.mme.gov.br/web/guest/pagina-inicial/outras-noticas/-/asset_ publisher/32hLrOzMKwWb/content/governo-lanca-o-novo-mercado-do-gas-um-marco-historico-para-obrasil.

${ }^{31}$ Resoluções CNPE - 2019. Ministério de Minas e Energia.

URL: http://www.mme.gov.br/web/guest/cnpe-2019.

32 Apêndice I: Leilão de eficiência energética: projeto piloto em Roraima: relatório de análise de impacto regulatório. Agência Nacional de Energia Elétrica. April 2018.

URL: https://www.aneel.gov.br/documents/656877/18485189/5+Modelo+de+AIR+-+SRM+-+Leilão+EE+

Roraima.pdf/ 30a2b6f5-b9a8-bcaa-aa85-6f2ce05984f3.

${ }^{33}$ Roraima - Planejamento Energético. Ministério de Minas e Energia.

URL: http://www.epe.gov.br/pt/publicacoes-dados-abertos/publicacoes/roraima-planejamento-

energetico\#PARTE03; OPEC share of world crude oil reserves, 2018. Organization of the Petroleum

Exporting Countries. URL: https://www.opec.org/opec_web/en/data_graphs/330.htm.

${ }^{34}$ Seelke C.R. Venezuela: overview of U.S. sanctions // In Focus. 16.10.2019. P. 1.

URL: https://fas.org/sgp/crs/row/IF10715.pdf.

${ }^{35}$ Estermínio de Melo I. As Crises do Petróleo e seus impactos sobre a inflação do Brasil // Pontifícia Universidade Católica do Rio de Janeiro. November 2018. P. 16.

URL: http://webcache.googleusercontent.com/search?q=cache:http://www.econ.puc-rio.br/uploads/adm/ trabalhos/files/Isabela_Esterminio_de_Melo.pdf.

${ }^{36}$ Forças Armadas darão apoio ao governo para evitar desabastecimentos por causa da greve dos caminhoneiros. Ministério da Defesa. 25.05.2018. URL: https://www.defesa.gov.br/noticias/43298-forçasarmadas-darão-apoio-ao-governo-para-evitar-desabastecimentos-por-causa-da-greve-dos-caminhoneiros.

37 Temer anuncia novo acordo para acabar com paralisação de caminhoneiros // Planalto. 27.05.2018. URL: http://www2.planalto.gov.br/mandatomicheltemer/acompanhe-planalto/noticias/2018/05/temeranuncia- novo-acordo-para-acabar-com-paralisacao-de-caminhoneiros; Medida Provisória № 832. De 27 de maio de 2018 // Diário Oficial da União. Edição: 100-C. Seção: 1 - Extra. P. 1.

URL: http://www.in.gov.br/web/dou/-/medida-provisoria-n-832-de-27-de-maio-de-2018-15967002?Inherit Redirect=true; Medida Provisória № 833. De 27 de maio de 2018 // Diário Oficial da União, Edição: 100-C. Seção: 1 - Extra. P. 1. URL: http://www.in.gov.br/web/dou/-/medida-provisoria-n-833-de-27-demaio-de-2018-15967015?inheritRedirect=true.

${ }^{38}$ Statistics data browser [Energy topic: imports/exports; Indicator: electricity imports vs. exports; country or region: Brazil]. International Energy Agency. URL: https://www.iea.org/statistics.

${ }^{39}$ Brazil electricity production // CEIC Data.

URL: https://www.ceicdata.com/en/indicator/brazil/electricity-production.

40 Brazil: executive summary. International Energy Agency. 18.04.2019. URL: https://www.eia.gov/beta/international/analysis.php?iso=BRA.

${ }^{41}$ Lillis K. Today in energy: hydropower supplies more than three-quarters of Brazil's electric power. International Energy Agency. 17.06.2014. URL: https://www.eia.gov/todayinenergy/detail.php?id=16731. 
42 Portaria № 339, de 15 de agosto de 2018 // Diário Oficial da União. Edição 159. Seção 1. P. 60. 17.08.2018. URL: http://www.in.gov.br/materia/-/asset_publisher/Kujrw0TZC2Mb/content/id/37211389/ do1-2018 -08-17-portaria-n-339-de-15-de-agosto-de-2018-37211296.

${ }^{43}$ Nota do MME sobre reunião extraordinária do Comitê de Monitoramento do Setor Elétrico. Operador Nacional do Sistema Elétrico. 04.10.2017. URL: http://www.ons.org.br/Paginas/Noticias/20171004notareuniaocmse.aspx.

44 Total energy production // Global Energy Statistical Yearbook 2019. Enerdata Intelligence \& Consulting, 2019. URL: https://yearbook.enerdata.net/total-energy/world-energy-production.html.

45 Total energy consumption 2019 // Ibid.

URL: https://yearbook.enerdata.net/total-energy/world-consumption-statistics.html.

${ }^{46}$ Fatos e tendências água // Agência Nacional de Águas. September 2009. P. 5.

URL: http://arquivos.ana.gov.br/imprensa/publicacoes/fatosetendencias/edicao_2.pdf.

47 Silveira D. Brasil tem mais de 208,5 milhões de habitantes, segundo o IBGE. G1. Instituto Brasileiro de Geografia e Estatística (IBGE), 29 August 2018.

URL: https://g1.globo.com/economia/noticia/2018/08/29/brasil-tem-mais-de-208-milhoes-de-habitantessegundo-o-ibge.ghtml.

${ }^{48}$ Fatos e tendências água. Op. cit. P. 5.

49 Silveira D. Brasil tem mais de 208,5 milhões de habitantes, segundo o IBGE // Globo.com. 29.08.2018. URL: https://g1.globo.com/economia/noticia/2018/08/29/brasil-tem-mais-de-208-milhoes-de-habitantessegundo-o-ibge.ghtml.

50 Fatos e tendências água. Op. cit. P. 5.

${ }^{51}$ Grandes apagões viram rotina no Brasil. Associação Nacional dos Consumidores de Energia. 2015. URL: http://www.anacebrasil.org.br/noticias/grandes-apagoes-viram-rotina-no-brasil.

${ }^{52}$ A crise do apagão // Iguaçu Energia. 15.10.2019. URL: http://www.ienergia.com.br/energia/ apagao.aspx.

${ }^{53}$ Vieira D. Geração de energia a gás natural é solução energética para apagões // Agência Alagoas. 25.04.2017. URL: http://agenciaalagoas.al.gov.br/noticia/item/15528-geracao-de-energia-a-gas-natural-esolucao-energetica-para-apagoes.

${ }^{54}$ Carstens L. Energia no Brasil: problemas e oportunidades // Gazeta do Povo. 06.10.2014.

URL: https://www.gazetadopovo.com.br/opiniao/artigos/energia-no-brasil-problemas-e-oportunidadeseeljt6y5x3105vffv93z8I5ji. 